\title{
Influence of International Performance Measurement on Curriculum and Assessment Policy
}

\author{
Ammar Husnain Khan \\ Room \# 105, Sinclair Hall, Forman Christian College (A Chartered University), Pakistan
}

\section{*Corresponding Author}

Ammar Husnain Khan

\section{Article History}

Received: 27.09.2020

Accepted: 13.10 .2020

Published: 20.10.2020

\begin{abstract}
The process of globalisation brings a huge impact around the world in the field of education. The third world countries are on the verge of making an influential change in their education system. The neoliberal structure being practiced at the present time is also enforcing the restructuring of education system in Pakistan. These changes seem to be shaping notions regarding the policies in education system of Pakistan. The educational polices will be reviewed along with the educational reforms in this paper and critically analysed which show that how curriculum and assessment are under influence of international performance measurement system. The basis of this study is to identify, analyse and evaluate the key drivers of these educational policies in Pakistan and what impact do they bring in the system. The paper also considers the fundamental concept of curriculum given by Dewey which gives a pretty clear idea that Pakistan needs immediate and good educational reforms that need to be implemented. Emphasis will be laid upon that Pakistan to compete in the global economy, needs an effective education system that can sustain and bring changes in the curriculum and assessment accordingly.
\end{abstract}

Keywords: Globalisation, assessment, curriculum, pedagogy, global education policy field, knowledge economy, international performance measurement.

\section{INTRODUCTION}

Education is a sustaining strength. It is the productive aspect for any nation [1]. It assists public to work for their progress and development. Henceforth, education brings out the unknown capabilities of people and cultivates them. Education is seemed now to be on the path to national progress. Education builds a sense of responsibility between the general public. People get to identify how to accomplish their individual, societal and national rights, and not just only recognise their sense of duty on the foundation of education. One of the important aims of education is to empower the individuals by improving their overall awareness concerning their international and national stance as general population of the world. This consciousness forms an impression of belief and collaboration in the world. How people play their individual part in the development of nation and therefore become prosperous and promote economic development is through education [2]. Pakistan is in development stages and as a country its economy is vulnerable. As a country, Pakistan's political steadiness lacks. Moreover, Pakistan is in the profound hold of growing economic deterioration, social insecurity, continuous sectarian violence, intensifying terrorism and political chaos [3]. Directly or indirectly all these issues are the sprout of a non-unified, diverged and pathetic system of education. Pakistan confronts with many difficulties today such as terrorism, sectarianism, insecurity and poverty [4]. Pakistan as a nation and even its people have led to low progress in all areas of life due to that the dynamic power of education has been deserted. The full picture behind these issues is illiteracy, lack of overall awareness and absence of tolerance that is stimulated by an ineffectual system of education [3]. In my view, the way a step child is treated, education has been given the same treatment. The important factor that gave rise to weakness of essentials of quality education in the system is also due to finances that have been granted to the education system ever since the creation of Pakistan happened. The education system of Pakistan has seriously been unsuccessful to take the country out of the increasing social, political and economic dilemma even by carrying out of many educational polices and after a period of almost 70 years [1]. Hence, by looking at the

Copyright (C) 2020 The Author(s): This is an open-access article distributed under the terms of the Creative Commons Attribution 4.0 International License (CC BY-NC 4.0) which permits unrestricted use, distribution, and reproduction in any medium for noncommercial use provided the original author and source are credited. 
current picture of Pakistan, it can be said that socially, politically, and economically as a nation, Pakistan has been unsuccessful due to the failure of the education system.

Lack of consistency, absence of research, weak administration and organization, corruption, obsolete curriculum, political intervention, dropouts on high scale, aimless education, low enrolment, no proper implementation of education policies, poor teaching quality, inadequate physical facilities, unreliable examination system and lack of adequate budget are some of the complications linked with the education system of Pakistan [5]. These are the problems that have continuously increasing without any effective measure to tackle them. Iqbal [6] said that these certain issues in the education system can be sorted out by construction of balanced or sensible plans and policies and by guaranteeing accurate execution of the policies. The bureaucratic interventions and political interference in all the systems of Pakistan makes it much difficult to happen till now.

\section{Pakistan's Context of Education Policy}

After the British left from India in 1947, Pakistan came up as a postcolonial country. The founders of Pakistan considered that educating the people have to be the most significant aspect in the progress of the new land. It can be seen in the initial educational session held (3 months after the independence) in November 1947. The founder of the state, Quaid-e-Azam Muhammad Ali Jinnah in his inaugural address said:

"There is no doubt that the future of our State will and must greatly depend upon the type of education and the way in which we bring up our children as the future servants of Pakistan. Education does not merely mean academic education, and even that appears to be of a very poor type. What we have to do is to mobilize our people and build up the character of our future generations ", [7].

However, later on and even until now different political parties came but this priority to education was never given a thought. Many policies and educational plans have been introduced and brought forward since the independence but, either not implemented properly or without great outcomes. The present literacy proportion of adults is $55 \%$ and for the school goers, either, undergo a generally low-quality education experience or drop out early [3]. Some relevant issues in the policies have to be underlined to figure out any discussion about Pakistani education system. The other issue which is significant in its terms is the issue of language of education, either it is Urdu, English, or local language. Discovering the exact combination of these significant language selections have remained a burning issue which often has risen up high sentiments [8]. There are different people with different views. Some see the national language as a symbol for unity among the nation, while others argue for their local language as part of their identity and familiarity. English is considered to be significant among people now for having financial gains. Third major problem refers to the education system that is class based. While this class division is not quite easy and there are many dark sides between them which also indicates the nature of problem. The state allots about $2 \%$ of GDP for education [9], which is not even entirely distributed. Documents regarding policies are generated by each successive government with high guarantees but very less accomplishments [10]. Not so recently, almost 6 years back, there occurred some significant constitutional changes which also affected education and are also needed to be mentioned here. In the year 2010, the 18th Amendment in the constitution was passed by the parliamentarians, which decentralised much control from central government and were transferred to provinces. The 18th Amendment gave more power and independence to the provinces in a number of fields, and education was one of them. Thus, with minimum federal coordination, each region is apparently free to change and modify its own education curriculum and look over the main concerns. This was seen as a significant move in Pakistan where historically, at federal level curriculum was closely monitored. Though, the effects of 18 th Amendment haven't emerged as yet but the federal Ministry of Education has been eradicated.

\section{Reforms in Curriculum}

After long periods of negligence and sluggishness, Curriculum Reforms seem to have been on the go since 2001 in Pakistan. In 2005 and 2006, curriculum of all subjects and grade levels went through a broad reform in answer to critiques [11]. The concerns about the curriculum that was in use were that it was driven ideologically, exclusionary, opinionated, generated stereotypes that are negative with outdated content and was much resistant to global changes, and all of this was leading to insignificant and poor education as documented by the latest National Education Assessment System reports [12]. In 2005, the reforms began which were set in three simultaneous proposals. First, the process of national education policy reform (NEPR); secondly, the task of the first ever national education census (NEC) [35, 36] and national curriculum reforms; and third, all service delivery units in education (Ministry of Education (MOE)). All of these three were important in Pakistan's education setting but they remained divided from each other, and why they remained divided, there has not been a proper debate to date on the problem and this question remains unanswered. The National Education Policy draft was not approved even after many years of process, consultations and thoughts, and without much public debate the new National Curriculum was unexpectedly officially accepted by the Cabinet. It was seen as a discrete action of the education ministry. The National Curriculum [13] nonetheless was the least dispersed 
paper and putting it into practice was intended for the academic year 2010. The years passed and still the implementation and results are to be seen.

Also, Secondary education is in essential need to counter the alike challenges of making more accessible and, at the same time, "improving quality and relevance of" secondary education ([14]. This is because the current curriculum is outdated and reforms are needed in order to make it effective in current time for which persistent efforts are required to make the curriculum valuable. For making provisions for the upcoming challenges, improvement in curriculum is very much a necessity. Akhtar [15] says that syllabus of a subject is supposed to be the agonising throb of a nation. The way the course design is made and dispersed by meeting the needs of the current time and then its implementation through teachers who are made to go through the process of training and education is very important to see its effects. The world is said to be a global village now where new information and ideas are coming up constantly. Many developing countries are now making improvements to their educational system through different means and measures. It is, hence, vital to revise our curriculum by acquainting with the new improvements in the relevant areas of study and acquiring knowledge [16].

\section{Outdated Curriculum and Failed Curriculum}

Curriculum is kind of a way or tool through which we achieve the objectives of education. The demands of the current times are not met by the curriculum in Pakistan. It is the kind of a traditional and pretty old curriculum that makes the learners to learn by rote memory, certain facts and figures without having a concern that education is the universal and holistic development of an individual. The curriculum has placed much emphasis on the learner's psychology which cannot be disproved in teaching and learning process. I believe that through the sociological, philosophical and psychological foundations of education, the objectives of education should be developed. And, also, the current curriculum does not meet the standards of education and research. The curriculum is not stimulating the interest of the learner for reflective observation, scientific knowledge, research and practical work; and rather, it stresses and focuses upon theory and memory [5]. Afzal [17] also says on the curriculum that:

''To make matters worse, teachers and examiners barely seem to realize that a curriculum reform has taken place. In particular, the teaching methods goals of the reform seem to have been lost along the way"

Another problem that arises is that the 2007 policy for the national textbooks and learning materials stated that for the textbook rights of writing, the private publishers would compete for that. To which the members of the board criticized that publishers hire authors who cost them very low and it results in textbooks of very poor quality [17]. Review committees were also formed who would comment on and also ask for changes to the submitted textbooks by the publishers.

To make problems worse, teachers and examiners hardly give the impression to realize that a curriculum reform has occurred. Traditional ways of teaching in the classes through lecture, this is the only way teachers use or have been using and there is no kind of activity based learning or is almost negligible. Even the goals of teaching techniques of the reform also appear to have been vanished along the way. Teachers still do involve in rote memory and examiners also assess it without a problem.

\section{Goals of Education and Curriculum in Pakistan}

The education system was proposed by the founders as the dynamic force behind all state objectives [6]. In 1974, the first education conference which was held in Karachi, it was decided that the system of education would truly relate to the needs of the people and would work conferring to the national goals of Pakistan. Muhammad Ali Jinnah, the founder of the nation said that the main objective of the education system is to promote national character of Pakistani people [18]. This national character would have a high sense of selfless service, social integrity and responsibility to the nation and moral values on behalf of the people. Several committees were constituted and educational commissions were formed to strengthen the role of education. Iqbal [6] said that implementation had been very poor and it is ironical to see that happen. Instead of making progress, Pakistan has suffered badly because of the quality of education. The detachment between the community and the educational institutions and widening gaps is another problem which has affected the system negatively. This gap can be the cause of distrust on the system or the people didn't see education as a tool to come up as good citizens and succeed as well. I do believe that in the education process parental involvement is very important for ensuring the aspect of quality education. The first school of a child is their home. The effective implementation of policies will remain a problem without the involvement of parents in the educational process and 'parental involvement can as well solve the problem of disparity' [2].

\section{Impact of the International Performance Measurement on the Curriculum and Assessment}

The importance associated to measuring of results over definite well demarcated indicators in the global education policy field is one of the most important noticeable features. At the global level of diverse categories, this has 
triggered a vast flow of quite a lot of educational stats. There is measurement of performance over educational targets; to see many countries as a standard over the scales, the tests are conducted, for example Trends in Mathematics and Science Study (TIMSS) and Program for International Students Assessment (PISA). Grek [19] calls this trend as 'governing by numbers', whereby many indicators are used for validating performance and for governing the education system. Changes in Pakistan's education system or curriculum are also seen as part and impact of international performance measures. As in Pakistan, educational policy makers are coming up with policies that are the influence of international measurement of performance and how to compete in the globalized knowledge economy. The following divided sections elaborate the impact of International Performance Measurement and what reforms were introduced in its result. In my view these policies were made out of international context and not with Pakistani education context as implementation of these polices require capital and capable competent educational administrators who can sort and work this into practice which in Pakistan's case is a problematic thing. However, still the results of these implemented policies are yet to be seen even with several promises made by the governing authorities.

\section{Standardisation}

In a global knowledge economy, an important aspect in improving the image of a country is the assessment results and indicators which demonstrate the comparative worth of people of any specific state. These standards also have possibility of forming standardisation through evaluating the results in certain ranges and of specific skills and as a result leading to prospective contracting down of different pedagogical and curricular options. Lawn \& Lingard [20] say that such standardizing developments have previously been prominent at minimum at the European level which assert to eventually a cohesive 'European education policy space'. Indication of a move towards benchmarking and standardization, there has been some developments happening in Pakistan. The committee, National Accreditation Council for Teacher Education (NACTE) has been lately advised and formed by the Higher Education Commission (HEC) to conserve the standards in teacher education. An organization called Sindh Teacher Education Development Authority (STEDA) was also notified by the provincial government of Sindh. For teachers in Pakistan now higher education commission has also established some standards. To fulfil international requirements, the length of degrees has also been stretched. Programs for students' evaluation at certain classes are likewise on the upswing. The provincial government of Sindh, through its Provincial Education Assessment Centre (PEACE) also conducted assessment of class four pupils in the capacity of mathematics and language. To spread out the assessment to other subjects and other grades plans are also being made.

\section{Decentralisation}

Since 1990s, most prominently across the globe a rise is seen in the system of government structures which were decentralised [21]. Not only from public but several members from nongovernmental and private sectors and are being involved due to the governments are getting involved in forms of governance which is more joined-up and networked [22]. The form of governance that is decentralized is generally preferred to guarantee equity and effectiveness. Rosenau [23] describes this as a drive from 'government to governance'. It can be said that different states including Pakistan are resorting towards more hands-off government and losing their control over its institutions because in my view, the states do not want to invest money into education and thus want the institutions to generate their own funding. This certainty has also leaded to governments implementing new ways of governance, such as governing by setting a system of benchmarks and targets, which Grek [19] has also referred to as 'policy by numbers'. Governments manage the education through distance by collection and publication of different data on performance standards which works as a substitute tool for government to demand higher performance. In 2001, President Pervez Musharraf introduced the decentralization reforms in Pakistan. The target of the reforms in particular was to decentralize the power to district level for high proficiency and more sovereignty at indigenous level along with streamlining the centralized administrative structure in the sector of education [24]. However, there were high suspicions about the accomplishment of decentralization aims at its premature stages due to the inadequate aptitude of educational administrators at the district level [25]. There is as well a significant increase in the maintenance and development of educational statistics in Pakistan which have led to numerous publications like: Provincial assessment results; National Education Assessment System's (NEAS) results; annual reports by the Education Management Information System (EMIS) on state of basic education indicators at provincial and national levels; reports on the targets achieved in MDGs (Millennium Development Goals) and Education for All (EFA); and National Education Census 2005. A step towards 'policy by numbers' can be proposed by the excess of stats. To avoid overstatement, I do recognize the intrinsic complications by the means the data is gathered and shown and its effect on governance by the system. However, after the decentralization of education by the 18th Amendment, the form of growth in these figures does proposes an increasing trend, which will further boost up as the need for such stats and figures increases in governance.

\section{System of Assessment and Examination}

There is a clear dissimilarity amongst the examination system used by the public and private schools. The complex level thinking is hardly ever being passed over and much of the assessment system is built upon recall and 
memory [26]. However, in schools of private sector, importance is generally positioned on the application of knowledge and not the simple replica of rote memory. These discrepancies add to students' changing opinion of themselves. The most terrible part of the problem is that the government has given up on schooling of public sector. Assessment is the evaluation of what students' have learned. It should be based on quantitative and qualitative practices to broadly assess the students' performance. The principles need to make sure the reliability and strength of the techniques or methods used in the procedure of assessment. Siddiqui [26] argues that in a position where disparities are made and continued on the foundations of students' teaching and assessment, surroundings, textbooks quality and socio-economic backgrounds hardly make the curriculum policy uniform and it cannot bring the important, sustainable and meaningful essential change. The assessment system of Pakistan just not only has the worth to assess the performance of students' systematically but it is also out of date. The examination system of Pakistan does not assess them in all characteristics of learning but only examines the students' memory [1]. Likewise, the system is under the influence of internal and external powers which have stimulated the inclination towards unlawful practices such as unfair means [3]. As a result of this the system of examination endorses rote learning which opposes the role of high scholarly influence of students such as analytical skills, reflection and critical thinking in the development of education.

\section{CONCLUSION}

The concept of global education policy field continues that a common set of education policy approaches above nation states are evolving, which have critical and severe effects on national education systems [27]. Therefore, a proper logical understanding of this statement would propose that there should be a national education policy field and opposes the global policy. At a global scale, in education policy, the global education field resides many important inclinations. The authority of these inclinations now is upheld by what is denoted to as Neoliberalism. As defined by Harvey [28]:

"Neoliberalism is in the first instance a theory of political economic practices that proposes that human wellbeing can best be advanced by liberating individual entrepreneurial freedoms and skills within an institutional framework characterized by strong private property rights, free markets, and free trade. The role of the state is to create and preserve an institutional framework appropriate to such practices. The state has to guarantee, for example, the quality and integrity of money." (p.2)

Through establishing the educational policy framework of Pakistan, I have tried to discuss so far that a global education policy field is evolving and its consequences are noticeable in the Pakistan's educational policies. Concisely, the global policy treats the part of data for the provision of the budget; its volume and regulation, put emphasis on competition and endorses the running of education system by privatized and decentralized structures [29]. As argued above, these developments are pretty apparent in Pakistan. Another important thing to see that is there are different forms of globalisation that contest for their domination and of that form some at instance been occupied by the Neoliberal globalization [30]. It is vital now to study how these neoliberal courses of action inclinations are building the place in Pakistani policy. Generally, it could be claimed that global education policy field enters in national educational policy field by informal ways which are as well sustained through substantial means. On the question of language, in order to resolve pressures due to national and global pressures, the White Paper [31] emphasizes the importance of English over national languages.

These cases have revealed how the state of Pakistan attempts to negotiate and line up with the global education policy and also attempts to alleviate the pressures ascending because of the collaboration of national and global education policy fields. Though, we have to be conscious of the element on which the power of the government rests on and Bourdieu [32, 34] has called that as 'national capital' which is the whole ability of the state established by a cooperative result of political, human and financial assets a state has. The states that are in the developing stages retain minor volume of these assets and therefore lesser 'national capital' to answer to the problems. Negotiations of state of Pakistan appears to have been dependent profoundly on informal resources used in the process of consultations and language of the White Paper because of the poor state capital which resulted in negotiated and distinct national education policy significances.

A reaction by the state of Pakistan reveals that the advent of global policy in the national policy field is not just a process of arrangement; relatively it must go by procedure of conciliation that brings about in a distinctive answer towards national policy. However, this is reliant upon the state, the resources that it holds; states like Pakistan who is in the developing process are in problematic condition at this point.

An important thing which is very clear is that we to a great extent need a reform in curriculum. The least objective could be of remove of historic and other blunders and preconceptions from the curriculum, and make sure that it does not break the Constitution of Pakistan [33]. In addition to improved way of reforming, generate analytical and tolerant people who can think critically and rigorously. On my self-composure level that the existing governmental regime will be the one to commence such a transformation, known their wrong policy verdicts on the curriculum and education concerns so far, the downhearted answer is, near to nothing. 


\section{REFERENCES}

1. Rehman, H., \& Khan, N. (2011). "The flaws in Pakistan's Education System", Abasyn Journal of Social Sciences, 4(1), 70-83.

2. Zaki, W. M. (1989). Evaluation of Education Plans and Projects, Islamabad: National Book Foundation

3. Ahmad, I., Rehman, K. U., Ali, A., Khan, I., \& Khan, F. A. (2014). Critical Analysis of the Problems of Education in Pakistan: Possible Solutions, International Journal of Evaluation and Research in Education (IJERE), 3(2), 79-84

4. Save the Children \& UNICEF. (2005). Disciplining The Child Practices and Impacts, NWFP: School \& Literacy Department

5. Louis, D. H. (1987). "The crises of Education in Pakistan”, Lahore: Vanguard Book Ltd.

6. Iqbal, M. (1981). "Education in Pakistan", Lahore: Aziz publishers.

7. Vision of the Quaid (1947) Retrieved 13 February 2018 from: http://pc.gov.pk/mtdf/Foreword,\%20Preface\%20and\%20President\%20Message/The\%2 0Vision\%20of\%20the\%20Quaid.pdf

8. Mustafa, Z. (2011). Tyranny of language in education: the problem and its solution, Karachi: Ushba Publishing

9. World Bank. (2014). Government expenditure on education as \% of GDP (\%), Retrieved 9 January 2018 from: http://data.worldbank.org/indicator/SE.XPD.TOTL.GD.ZS

10. Ahsan, M. (2003). An analytical review of Pakistan's educational policies and plans, Research Papers in Education, 259-280

11. Aly, J. H. (2007). Education in Pakistan a White Paper revised - document to debate and finalize the National Education Policy, Retrieved 18 December 2017 from: http://www.moe.gov.pk/nepr

12. NEAS. (2006). Report of the first national stakeholder conference, Islamabad: Ministry of Education, Retrieved 26 November 2017 from: http://www.neas.gov.pk/Document\%20Center_files/National_Stakeholder_2006.pdf

13. National curriculum. (2006). Education and Literacy Department, Government of Sindh Retrieved 14 December 2017 from: http://www.sindheducation.gov.pk/nationalCurriculum/nationalCurriculum.jsp

14. World Bank Policy Paper. (2011). Expanding Opportunities and Building Competencies for Young People: A New Agenda for Secondary Education, Retrieved 17 January 2018 from: http://web.worldbank.org/WBSITE/EXTERNAL/TOPICS/EXTEDUCATION/0,,menuPK:2823 93 pagePK:162100 piPK:159310 theSitePK:282386,00.html

15. Akhtar, M. (2004). Unpublished thesis of PhD Education: analysis of curriculum process and development of a model for secondary level in Pakistan, Retrieved 17 Decemer 2017 from: http://eprints.hec.gov.pk/580/1/292.html.htm

16. Higher Education Commission. (2003). Revised Curriculum of Pakistan studies, Retrieved 13 February 2018 from:http://www.hec.gov.pk/InsideHEC/Divisions/AECA/CurriculumRevision/Documents/549

_Pakistan_studies_Compulsory.pd

17. Afzal, M. (2014). A Failed Curriculum Reform, Retrieved 18 January 2018 from: http://www.brookings.edu/research/opinions/2014/01/15-pakistan-curriculum-reform-afzal

18. Qurashi, I. H. (1975). "Education in Pakistan", Karachi, Maaref LTD.

19. Grek, S. (2009). Governing by numbers: the PISA 'effect' in Europe, Journal of Education Policy, 23-37

20. Lawn, M., \& Lingard. (2002). Constructing a European policy space in educational governance: the role of transnational policy actors, European Educational Research Journal, 1, 290-307

21. McGinn, N., \& Welsh, T. (1999). Decentralization of education: why, when, what and how? Paris: UNESCO: International Institute for Educational Planning.

22. Mok, K. (2005). "Globalisation and governance: educational policy instruments and regulatory arrangements", International Review of Education, 51, 289-311

23. Rosenau. (2000). Governance, order, and change in world politics, Cambridge: Cambridge University Press

24. Memon, M. (2005). Policy reforms for decentralizing education system in Pakistan: prospects and challenges, Sydney, Australia

25. Ali, S., Alvi, U., Babur, M., \& Rizvi, M. (2006). Capacity building and decentralization at district level - Report on the ESRA research project, Karachi: Aga Khan University

26. Siddiqui, S. (2010). Myth of one curriculum, Retrieved 12 February 2018 from: http://shahidksiddiqui.blogspot.co.uk/search?updated-max=2010-04-25T18:22:00-07:00\&maxresults $=7 \&$ start $=77 \&$ by-date $=$ false

27. Ozga, J., \& Lingard, B. (2007). Globalisation, education policy and politics. The Routledge Falmer reader in education policy and politics, 65-82.

28. Harvey, D. (2005). A brief history of neoliberalism, Oxford: Oxford University Press, Retrieved 2 February 2018 from: http://www.sok.bz/web/media/video/ABriefHistoryNeoliberalism.pdf

29. Hameed-ur-Rehman, M., \& Sewani, S. M. S. (2013). Critical analysis of the educational policies of Pakistan. The Dialogue, 8(3), 247-260

30. Santos, B. S. (2002). The process of globalization, Eurozine, 68, 1-45 
31. White Paper. (2007). National Education Policy Review, Retrieved 11 January 2018 from: https://www.academia.edu/5576636/Pakistan_National_Education_Policy_Review_Whi te_Paper

32. Bourdieu, P. (2003). Firing back: against the tyranny of the market, London: Verso

33. Constitution of Pakistan. (2012). The Constitution of the Islamic Republic of Pakistan, Retrieved 22 January 2018 from: http://www.na.gov.pk/uploads/documents/1333523681_951.pdf.

34. Dewey, J. (1950). Philosopher of science and freedom, In: S. Hook. (Ed.), A Symposium, New York: Barnes \& Noble, Inc.

35. Ministry of Education. (2009). National Education Policy 2009, Islamabad: Government of Pakistan, Retrieved 3 January 2018 from: http://www.aserpakistan.org/document/learning_resources/2014/National\%20Educatio n\%20Policy\%202009.pdf

36. Ministry of Education. (2013). Year Book, Retrieved 18 January 2018 from: http://moent.gov.pk/gop/index.php?q=aHR0cDovLzE5Mi4xNjguNzAuMTM2L21vcHR0bS91c2VyZmlsZXMxL2Z pbGUvWWVhciUyMEJvb2tzL11lYXIIMjBCb29rMjAxMS0xMi5wZGY\% 3D 